Article

\title{
Analyzing Factors Affecting the Sustainability of Land Management Practices in Mecha Woreda, Northwestern Ethiopia
}

\author{
Habtamu Nebere ${ }^{1,2, * \mathbb{D}}$, Degefa Tolossa ${ }^{1}$ and Amare Bantider ${ }^{1}$ \\ 1 College of Development Studies, Addis Ababa University, Addis Ababa 1000, Ethiopia; \\ degefatd@gmail.com (D.T.); amare.bantider@gmail.com (A.B.) \\ 2 Department of Geography and Environmental Studies, Woldia University, Woldia 7220, Ethiopia \\ * Correspondence: habtamunebere@yahoo.com
}

Citation: Nebere, H.; Tolossa, D.; Bantider, A. Analyzing Factors Affecting the Sustainability of Land Management Practices in Mecha Woreda, Northwestern Ethiopia. Sustainability 2021, 13, 7007. https://doi.org/10.3390/su13137007

Academic Editor:

Anastasios Michailidis

Received: 12 April 2021

Accepted: 9 June 2021

Published: 22 June 2021

Publisher's Note: MDPI stays neutral with regard to jurisdictional claims in published maps and institutional affiliations.

Copyright: (c) 2021 by the authors. Licensee MDPI, Basel, Switzerland. This article is an open access article distributed under the terms and conditions of the Creative Commons Attribution (CC BY) license (https:// creativecommons.org/licenses/by/ $4.0 /)$.

\begin{abstract}
In Ethiopia, the practice of land management started three decades ago in order to address the problem of land degradation and to further boost agricultural production. However, the impact of land management practices in curbing land degradation problems and improving the productivity of the agricultural sector is insignificant. Various empirical works have previously identified the determinants of the adoption rate of land management practices. However, the sustainability of land management practices after adoption, and the various factors that control the sustainability of implemented land management practices, are not well addressed. This study analyzed the factors affecting the sustainability of land management practices after implementation in Mecha Woreda, northwestern Ethiopia. The study used 378 sample respondents, selected by a systematic random sampling technique. Binary logistic regression was used to analyze the quantitative data, while the qualitative data were qualitatively and concurrently analyzed with the quantitative data. The sustained supply of fodder from the implemented land management practices, as well as improved cattle breed, increases the sustainability of the implemented land management practices. While lack of agreement in the community, lack of enforcing community bylaws, open cattle grazing, lack of benefits of implemented land management practices, acting as barrier for farming practices, poor participation of household heads during planning and decision-making processes, as well as the lack of short-term benefits, reduce the sustainability of the implemented land management practices. Thus, it is better to allow for the full participation of household heads in planning and decision-making processes to bring practical and visible results in land management practices. In addition, recognizing short-term benefits to compensate the land lost in constructing land management structures must be the strategy in land management practices. Finally, reducing the number of cattle and practicing stall feeding is helpful both for the sustainability of land management practices and the productivity of cattle. In line with this, fast-growing fodder grass species have to be introduced for household heads to grow on land management structures and communal grazing fields for stall feeding.
\end{abstract}

Keywords: sustainability; determinant factors; sustainable land management; logistic regression; Ethiopia

\section{Introduction}

Agriculture, which is characterized by subsistence crop farming and livestock rearing, is the mainstay of the Ethiopian economy. The share of agriculture accounts for approximately $46 \%$ of the Gross Domestic Product, $73 \%$ of employment and nearly $80 \%$ of foreign export earnings [1]. However, the degradation of land resources in Ethiopia has resulted in the large-scale deterioration of agricultural productivity and the country's economic development [2]. Kassie et al. [3] further discussed the ways in which Ethiopian agriculture is challenged by soil erosion and declining productivity, which further pose a problem to the efforts of poverty reduction and aggravate food insecurity problems. The productivity losses in agriculture, due to land degradation, are predicted to reduce the 
annual agricultural Gross Domestic Product by 17\%, as noted by Amede et al. [4], while Agricultural Transformation Agency of Ethiopia (ATA) [1] estimated a 3\% annual loss of agricultural Gross Domestic Product. In accord with this, Kassie et al. [5] described the manner in which the productivity losses in agriculture, due to land degradation, made the country dependent on food aid. The main cause of land degradation in Ethiopia comprises rapid population growth, deforestation, overgrazing, over cropping and inapt farming practices [6-8]. Similarly Deichert et al. [9] noted inappropriate land use and deforestation, which are triggered by alarming population growth and uncontrolled grazing, which brought about severe land degradation in the Ethiopian highlands. Population pressure leads to deforestation and the conversion of pasture land into farmlands, further intensifying land degradation [10]. Sustainable land management practices have the widespread purpose of improving agricultural production and the livelihoods of people through the preservation and enhancement of ecosystem services for all land uses [11-13]. This consists of soil and water conservation, conservation agriculture, natural resource management and ecosystem management in order to address the integrated social, economic and physical needs of the people [14]. Sustainable land management enhances fodder and wood production, soil protection and increased fertility, as well as biodiversity, while the socio-cultural benefits include strengthening community institutions, increased income, and improved household nutrition [15]. The effective implementation of sustainable land management practices delivers social and economic benefits through enhanced and resilience agroecosystems, which are needed to address the challenges facing the world today, such as food security and climate change [16]. Generally, the implementation of land management practices will enhance environmental, social and economic sustainability [17].

To curb the challenges of land degradation, various governmental and non-governmental organizations have been practicing land management measures in Ethiopia. The main land management measures have been practiced under the food-for-work (FFW) program (1973-2002), managing environmental resources to enable a transition to more sustainable livelihoods (MERET, 2003-2015), productive safety net programs (PSNP, 2005-present), community mobilization through free-labor days (1998-present) and the national sustainable land management project (SLMP, 2008-2018) [18]. These implemented land management practices, however, are not effective in bringing about the expected changes. As noted by Gebremedhin et al. [19], the intervention strategies prior to the 1990s were more technology oriented and followed a top-down approach; their impact was insignificant. Various soil and water conservation practices, such as the use of stone terraces, soil bunds and area closures, which are implemented with the support of external aids and donors, are limited to bring the expected results on land resources and the livelihoods of people [20]. According to Sileshi et al. [21] and Tesfaye et al. [22], though there were various efforts towards improving land management practices, the problem of land degradation remains a serious challenge. Land management practices mostly comprised seasonal campaigns, and the measure of success was more in terms of area coverage than the quality of measures to bring about the intended benefits, and this made the practices unsustainable [19,23].

In most places, implemented sustainable land management practices are either totally or partially removed by farmers [24]. A survey of land management practices in the Amhara region also showed that only 30\% of the implemented land management structures of the past two-and-a-half decades of conservation works has survived [25]. Similarly Amede et al. [4] stated that the one year survival rate of planted trees is as low as $0-15 \%$, and the physical structures are soon destroyed. The lack of participation of local communities in planning and decision-making processes, the lack of returns from implemented land management practices, land fragmentation, the failure to consider farmers' livelihoods in land management practices, and the lack of short-term benefits all limit the sustainability of the implemented land management practices [3,4,20,26-28]. Furthermore, Tefera and Sterk [29] noted how the loss of land for land management measures, as well as the high labor needs for maintenance and execution, reduces the long-term viability of established land management methods. Due to a lack of livestock feed sources, farmers 
were compelled to conduct open grazing, which has harmed the sustainability of land management methods. Tesfaye et al. [30] verified that large-scale cattle ownership, which is difficult to manage in stall feeding, has a detrimental impact on land management practice adoption and sustainability.

The majority of prior empirical investigations identified the determinants of land management practice adoption. Land size, access to information (extension services), livestock ownership, land tenure system, social capital, family labor availability, failure to link conservation to livelihoods, weak organizational and institutional arrangements, profitability of land management practices, plot distance from home, slope and fertility of farm plots and age of household heads are all factors that influence the adoption rate of land management practices [3,31-37]. Moreover, Teshome et al. [16] stated that community members' collaboration and trustworthiness (social capital) boosted the likelihood of land management investments. Wossen et al. [38] discovered that being a member of a local credit and savings association, having labor exchange arrangements, and being connected to local authorities has a considerable and favorable impact on land management practices. In another study, Wossen et al. [39] found that membership in both formal and informal associations reduced the rate of adoption of land management practices. Furthermore, a study conducted by Belay and Bewket [40] in northwestern Ethiopia found that labor scarcity, land tenure insecurity, and plot distance from home all have negative effects on manure application, whereas large livestock holdings and maize-vegetable-fruit intercropping improve manure application on farm plots. Though the aforementioned empirical research looked at numerous determinant elements in the early adoption of land management methods, they were limited in defining what factors affect the sustainability of those methods after implementation. Land management practices are popular in Mecha Woreda (administrative unit parallel to district) of northwestern Ethiopia. Every year, as part of a countrywide effort, a one-month campaign of land management practice is carried out across the entire Woreda. The long-term sustainability of the implemented land management practices is, however, in doubt. The implemented land management practices lack long-term viability and tangible benefits to natural resources and rural farmer livelihoods. This predicament raised the question of what variables contribute to the unsustainable land management methods that have been adopted. As a result, the subject of land management methods' un-sustainability has caused researchers to look for elements that influence the sustainability of land management practices in the study area. Therefore, the primary goal of this research is to investigate the factors that influence the sustainability of land management practices after adoption.

\section{Materials and Methods}

\subsection{Description of the Study Area}

The study area, Mecha Woreda, is located in the Amhara national regional state's West Gojjam Administrative Zone (Figure 1). It is located $515 \mathrm{~km}$ north of Addis Ababa, the country's capital, and $37 \mathrm{~km}$ southwest of Bahir Dar, the region's city. Merawi, the Woreda's capital, is located on the main road connecting Addis Ababa and Bahir Dar. Astronomically, the Woreda is located between $11^{\circ} 05^{\prime} \mathrm{N}$ to $11^{\circ} 38^{\prime} \mathrm{N}$ and $37^{\circ} 00^{\prime} \mathrm{E}$ to $37^{\circ} 23^{\prime}$

E. The Woreda's entire area is approximately 156,027 ha with flat terrain accounting for $75 \%$, undulated topography for $13 \%$, and mountains and valley topographies accounting for the remaining $8 \%$ and $4 \%$, respectively [41]. The current geomorphic surface configurations are the consequence of tertiary structural processes such as faulting and uplifting, which are changed by quaternary external processes such as recent volcanic denudation and sedimentation [42]. 


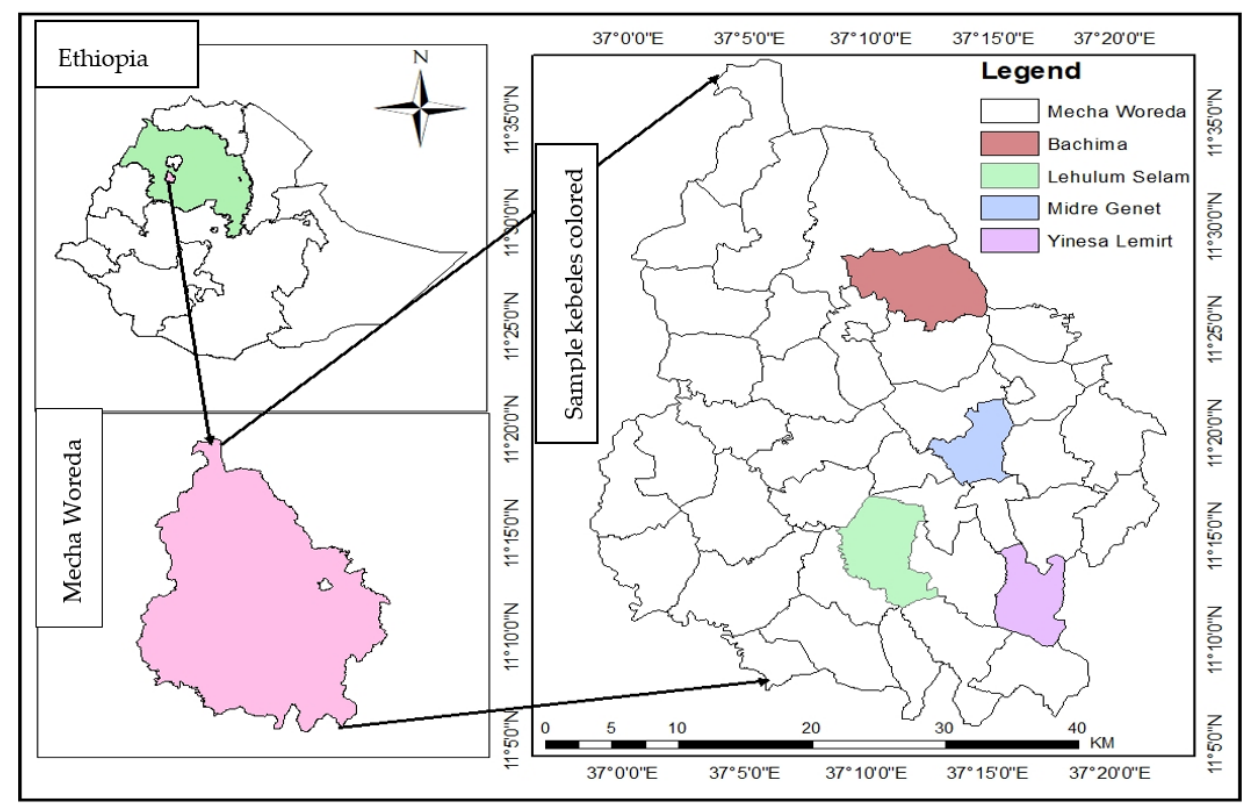

Figure 1. Map of the Study Area (Source: Author).

The agro-climate of Mecha Woreda is primarily sub-tropical (locally known as Woinadega), accounting for roughly $80 \%$ of the area, and temperate (locally known as Dega) accounting for the remaining $20 \%$. The Woreda is located at an elevation of $1800-2500 \mathrm{~m}$ above sea level. It receives an average annual rainfall of 820 to $1250 \mathrm{~mm}$. The area's daily lowest and highest temperatures are 17 and $30^{\circ} \mathrm{C}$, respectively [43]. Nitisol is the most common soil type in the Woreda, accounting for $93 \%$ of the total area, with Andosol and Vertisol accounting for the remaining 3\% and 4\%, respectively [41]. Andropogoan, Cynodon, Digitaria, Typha, and Reeds are the dominant grasses in the grazing areas. Albizziagummifera, Cordia Africana, Ficus Sycomorus, Veronica amygdalina, Erythrina abyssinica, Dombeyasp. Syzygiumguineens, and Prunus Africana are the prominent tree and shrub species [42]. The Woreda's livelihood strategy is mixed farming and is performed at a subsistence level in dispersed farms that are largely lacking modern technology. The major food crop types grown in the Woreda consist of cereals $(70.95 \%)$, oil crops $(17.96 \%)$, pulses $(5.07 \%)$, vegetables and fruits $(4.85 \%)$, spices $(1.02 \%)$ and others $(0.14 \%)$ [34]. The production of livestock is also regarded as an important economic activity in the area. Livestock breeding, which is dominated by local breeds, is also considered as a valuable source of food, money, draught power, and commodities transportation. Cattle $(245,147)$, poultry, goats, and sheep $(156,805)$, equines (mule, horse, and donkey $(27,695)$, and bees (traditional and modern apiculture) $(25,862)$ make up the livestock population of Mecha Woreda [35]. The average land holding per household in the Woreda is 0.94 ha, ranging from 0 to 3 ha among the Woreda's farmers.

\subsection{Research Design}

For the purpose of triangulating quantitative and qualitative data, this study used a concurrent mixed research design. The concurrent mixed research method combines quantitative and qualitative data at the same time, allowing the benefits of both methodologies to be captured while the shortcomings are eliminated. The main benefit of concurrent mixed methods design is that one type of data collection compensates for the shortcomings of the other, resulting in a more full grasp of the study subject [44]. This approach allows for simultaneous triangulation and comparison of qualitative and quantitative data. As the study technique is mixed concurrent, both quantitative and qualitative data were collected and analyzed simultaneously. The data for this study were gathered using a structured questionnaire survey, focus group discussion, key informant interview, and observation. 


\subsection{Sample and Sampling Procedure}

The target groups for the survey were the residents of Mecha Woreda, mainly the rural community. Both probability and non-probability sampling strategies were used in the sampling operation. The probability sampling methodology was used to choose sample respondents through a multi-stage sampling technique. First, the Woreda was divided into two agro-climatic zones: Woinadega and Dega, with three kebeles (the smallest administrative unit) chosen at random from the Woinadega agro-climatic zone: Lehulum Selam, Midregenet, and Bachima, and one kebele from the Dega agro-climatic zone: Yinesa Lemirt. Then, using a systematic random sampling technique, the appropriate sample respondents were drawn from the randomly selected kebeles. Using the formula in [45], 378 sample household heads were selected from a total of 6983 household heads. The whole sample was then proportionally distributed across the four kebeles, and the required number of sample household heads in each kebele was chosen using a systematic random sampling approach. In addition, key informants and participants in focus group discussions were chosen using a non-probability sampling methodology based on their proximity to the subject being investigated. Development agents and Woreda experts were key informants. The members in the focus group discussion were chosen specifically for their suitability for the topic, and the group took into account heterogeneity in terms of age, sex, relative economic status, and responsibilities in the community.

\subsection{Definition and Description of Variables}

Several factors influence the long-term viability of land management practices after they are implemented. Allocating communal grazing fields to individuals, sustained supply of cattle fodder, lack of community agreement, ownership of improved cattle breeds, lack of enforcing community bylaws, open cattle grazing, lack of supervision from development agents, low quality of implementation, low benefits, barriers for farming practices, poor participation of household heads during planning and decision making and lack of short term benefits are the main factors that determine the sustained and continuous use of land management practices. The year-round availability of cattle fodder (a consistent supply of cattle fodder) allows communities to adopt stall feeding, which helps to ensure the sustainability of land management methods. The community must agree on where, how, and what type of land management methods are applied in their area when it comes to land management practices. The lack of agreement in the community about the aspects of land management methods reduce the sustainability of land management practices. The implementation of land management structures that are below standard, as well as the lower benefits of implemented land management practices that are below the intended value, have a detrimental impact on the long-term viability of land management practices. Involving household heads in the planning and decision-making processes of land management practices allows household heads to be in charge of the adopted land management methods in terms of both maintenance and implementation at the outset, as well as the long-term viability of the works. In land management practices, considering the nature of economic activity and the needs of household heads when selecting and constructing land management structures has a long-term effect on the sustainability of land management practices; ignoring the above concerns in land management methods may cause difficulties in farming operations (by acting as a barrier during farming) and it may not provide the intended benefits in the short term, thereby further reducing the sustainability of the practices. The following table (Table 1) lists the factors that influence the sustainability of land management methods after they are adopted. 
Table 1. Description of explanatory variables included in the binary logit model.

\begin{tabular}{|c|c|c|c|}
\hline Explanatory Variable & Type of Variable & Expected Relationship & Description of the Variable \\
\hline agri & Binary & + & $\begin{array}{l}\text { Allocating communal grazing fields to individuals } \\
\qquad(1=\text { yes } 0=\text { no })\end{array}$ \\
\hline ssf & Binary & + & Sustained supply of fodder $(1=$ yes $0=$ no $)$ \\
\hline lagr & Binary & - & $\begin{array}{l}\text { Lack of agreement in the community } \\
\qquad(1=\text { yes } 0=\text { no })\end{array}$ \\
\hline imbr & Binary & + & $\begin{array}{l}\text { Ownership of improved cattle breed } \\
\qquad(1=\text { yes } 0=\text { no })\end{array}$ \\
\hline laec & Binary & - & $\begin{array}{l}\text { Lack of enforcing community bylaws } \\
\qquad(1=\text { yes } 0=\text { no })\end{array}$ \\
\hline ocgr & Binary & - & Open cattle grazing $(1=$ yes $0=$ no $)$ \\
\hline lasda & Binary & - & $\begin{array}{l}\text { Lack of supervision of development agents } \\
\qquad(1=\text { yes } 0=\text { no })\end{array}$ \\
\hline logi_1 & Binary & - & Low quality of implementation $(1=$ yes $0=$ no $)$ \\
\hline lobe & Binary & - & Low benefits $(1=$ yes $0=$ no $)$ \\
\hline bafp & Binary & - & Barrier for farming practices $(1=$ yes $0=$ no $)$ \\
\hline pap & Binary & - & $\begin{array}{l}\text { Poor participation in planning and decision } \\
\text { making }(1=\text { yes } 0=\text { no })\end{array}$ \\
\hline lasb & Binary & - & Lack of short term benefits $(1=$ yes $0=$ no $)$ \\
\hline Dependent variable & Sustainability of the im & land management practices & $\begin{array}{c}1 \text { = Continuous land management practice and } \\
\text { cut-and-carry system of grazing } \\
\text { together; } 0 \text { otherwise }\end{array}$ \\
\hline
\end{tabular}

Source: Literature review and field survey by the author.

\subsection{Data Analysis}

Sustainable land management has been defined in various ways. The World Bank [46] defined it as a knowledge-based procedure that helps to integrate land, water, biodiversity and environmental management to meet rising food and fiber demands while sustaining ecosystem services and livelihoods. According to Hurni [47], sustainable land management is a set of technologies that blend ecological, economical, and political principles into land management while considering future intergenerational equity. Furthermore, Liniger et al. [48] defined sustainable land management as the utilization of land resources such as soil, water, animals, and plants to fulfill the evolving needs of humans while also preserving their productive potential. However, for the purpose of this study, the definition of sustainable land management is specified as follows. Sustainable land management is the use of physical and biological land management practices integrated with protected grazing (cut-and-carry system). Therefore, sustainable land management here is implementing land management practices with protected grazing (cut-and-carry system) together. According to this definition, a household is said to be an adopter of sustainable land management if it has continuously implemented any physical and biological land management practices, as well as a protected livestock grazing (cut and carry) system, from the first application stage to the present, with appropriate maintenance each year. As a result, the adopted land management practices' sustainability can be thought of as a binary dummy variable $(1=$ adopting and utilizing constantly through maintenance and protected grazing, $0=$ otherwise). The logit and probit regression models are the best methodologies for estimating binary dummy dependent variable regression models. The logit model is utilized for this purpose since it is simple to implement. The following is the abbreviated form of the logit model used in this investigation.

$$
y_{i}=\beta_{0}+\beta_{1} X_{1}+\beta_{2} X_{2}+\beta_{3} X_{3}+\ldots+\beta_{n} X_{n}+\beta_{n} Z_{i}+\varepsilon_{i}
$$

where $y_{i}=$ sustainability of the adopted land management practices, $X_{1}, X_{2}, X_{3}, \ldots, X_{n}=$ factors affecting the sustainability of land management practices, $Z_{i}=$ vector of country fixed effects and $\varepsilon_{i}=$ the error term.

The major outcome of this study is to determine whether the land management practice is sustainable, which is defined as the continued use of a land management practice after it has been adopted, integrated with protected grazing (cut-and-carry system) or not. Based on the empirical literature, 12 potential predictors of sustainability of land 
management practices were identified: allocating communal grazing fields to individuals, sustained supply of cattle fodder, lack of agreement in the community, ownership of improved cattle breed, lack of enforcing community bylaws, open cattle grazing, lack of supervision from development agents, low quality of implementation, low benefits, barrier for farming practices, poor participation of household heads during planning and decision making and lack of short term benefits. The determinants of sustainability of the implemented land management practices were studied using binary logistic regression. The presence of multicollinearity among the explanatory variables was verified using the variance inflation factor (VIF) prior to starting the logistic regression analysis. All of the explanatory variables' VIF values were reported to be very low, indicating that there was no multicollinearity between them. As a result, the final analysis incorporated all of the explanatory variables. The Hosmer-Lemeshow goodness of fit test was also used to test the model fit. The quantitative data were analyzed by binary logistic regression using STATA 15. The qualitative data collected through key informant interview, focus group discussions, observation and open-ended questionnaire were analyzed qualitatively under similar themes to the quantitative data.

\section{Results}

\subsection{Background Characteristics of Respondents}

The background information of sample household heads is covered in this section, which includes gender, age, marital and educational status, as well as the size of the land holding. The majority of the households in the sample are headed by men. According to the report, $92.3 \%$ of households are led by men, while $7.7 \%$ are led by women. The marital status of sample respondents is characterized as $95 \%$ married, and the other $4.2 \%, 0.5 \%$ and $0.3 \%$ are divorced, widowed and unmarried, respectively (Table 2). As couples make up the majority of sample respondents, this may have a positive influence in responsibility sharing and land management methods. Household productivity is determined by age in all facets of life. A household with a productive workforce contributes positively to all aspects of community life, including land management. The average age of sample respondents is 46.6 years old, with a minimum and maximum age of 21 and 80 years old, respectively. Of the total sample respondents, $4.5 \%, 25 \%, 34.9 \%$ and $28 \%$ are in the age category of 21-30, 31-40, 41-50 and 51-60 years old, respectively (Table 2). The remaining 6.6\% and $1 \%$ are in the age category of $61-70$ and $71-80$ years old, respectively. According to the aforementioned data, the majority of sample respondents $(92.3 \%)$ are in the productive age group, which is critical for implementing and maintaining sustainable land management practices. The other element that has a higher impact on the labor force contribution in a given household is the size of the family. From the total sample respondents, $24.3 \%$ and $59.5 \%$ of them have $2-4$ and 5-7 family members, correspondingly. The remaining $15.6 \%$ and $0.5 \%$ of the sample respondents have $8-10$ and $11-13$ family members, respectively. The average family size of sample respondents is 5.8 , and the minimum and maximum family sizes are 2 and 12, respectively. The educational backgrounds of sample respondents reveal that half of the respondents have no prior educational experience. According to the data, $51.8 \%$ sample respondents cannot read or write; $31.5 \%$ and $6.4 \%$, respectively, have adult and religious education (Table 2 ). The remaining $7.1 \%, 2.7 \%, 0.3 \%$, and $0.3 \%$ of respondents, respectively, are in grades $1-4,5-8,9-12$, and above 12 . As rural farm households' total livelihood strategies are directly linked to land, landholding size is a critical asset in their well-being. Sample respondents' landholding sizes range from 0 to 3 ha, with an average of 0.94 ha. Among the sample households, $1.6 \%$ of them have no land at all, while $34.1 \%$ and $42.3 \%$ of the respondents have a land size within a range of $0.25-0.75$ and $1-1.25$ ha of land, respectively. The other $19.6 \%$ and $2.4 \%$ of the sample household respondents have a land size within a range of $1.5-1.75$ and $2-3$ ha of land, respectively. 
Table 2. Background characteristics of household heads.

\begin{tabular}{|c|c|c|c|}
\hline Variable & Category & Freq. & Percent \\
\hline \multirow{3}{*}{ Gender } & Female & 29 & 7.7 \\
\hline & Male & 349 & 92.3 \\
\hline & Total & 378 & 100 \\
\hline \multirow{5}{*}{ Marital status } & Not married & 1 & 0.3 \\
\hline & Married & 359 & 95 \\
\hline & Widowed & 2 & 0.5 \\
\hline & Divorced & 16 & 4.2 \\
\hline & Total & 378 & 100 \\
\hline \multirow{8}{*}{ Educational status } & Adult education & 119 & 31.5 \\
\hline & Religious education & 24 & 6.4 \\
\hline & Not read and write & 196 & 51.8 \\
\hline & Grade $1-4$ & 27 & 7.1 \\
\hline & Grade 5-8 & 10 & 2.7 \\
\hline & Grade 9-12 & 1 & 0.3 \\
\hline & Grade above 12 & 1 & 0.3 \\
\hline & Total & 378 & 100 \\
\hline \multirow{7}{*}{ Age group } & $21-30$ & 17 & 4.5 \\
\hline & $31-40$ & 94 & 25 \\
\hline & $41-50$ & 132 & 34.9 \\
\hline & $51-60$ & 106 & 28 \\
\hline & $61-70$ & 25 & 6.6 \\
\hline & $71-80$ & 4 & 1 \\
\hline & Total & 378 & 100 \\
\hline \multirow{5}{*}{ Family size } & $2-4$ & 92 & 24.3 \\
\hline & $5-7$ & 225 & 59.5 \\
\hline & $8-10$ & 59 & 15.6 \\
\hline & $11-13$ & 2 & 0.5 \\
\hline & Total & 378 & 100 \\
\hline \multirow{6}{*}{ Land size } & 0 & 6 & 1.6 \\
\hline & $0.25-0.75$ & 129 & 34.1 \\
\hline & $1-1.25$ & 160 & 42.3 \\
\hline & $1.5-1.75$ & 74 & 19.6 \\
\hline & 2-3 & 9 & 2.4 \\
\hline & Total & 378 & 100 \\
\hline
\end{tabular}

Source: Field survey data processed by the author.

\subsection{Factors Affecting the Sustainability of the Adopted Land Management Practices}

This section examines the elements that influence the long-term viability of land management methods once they are implemented. The results of the binary logistic regression model estimated using the maximum likelihood method is shown in Table 3. The results show that the model is very significant $\left(\mathrm{Prob}>\mathrm{chi}^{2}=0.0000\right)$ and fits the data well. The Hosmer-Lemeshow goodness of fit test also fails to reject the null hypothesis, indicating that the model is a good fit to the data (Table 3). In a binary logistic regression model with robust standard error, 9 of the 12 variables are determined to be significant. Table 3 shows that maintaining a steady supply of cattle fodder and owning improved cattle breed increases the long-term viability of land management practices; lack of community agreement, failure to enforce community bylaws, open cattle grazing, low benefits, acting as a barrier to farming practices, poor participation of household heads during planning and decision-making, and a lack of short-term benefits are all factors that have a negative impact on the sustainability of land management practices after adoption. The variables of distributing community grazing grounds to individual users, absence of development agent oversight, and poor quality of land management practice execution are insignificant. 
Table 3. Binary logit results on determinants for the sustainability of the implemented land management practices.

\begin{tabular}{|c|c|c|c|}
\hline \multirow{2}{*}{ Explanatory Variables } & \multicolumn{3}{|c|}{$\begin{array}{c}\text { Dependent Variable (Sustainability of the Implemented Land } \\
\text { Management Practices) }\end{array}$} \\
\hline & Coefficient & Standard Error & $p$-Value \\
\hline Allocating communal grazing fields to individuals (agri) & $0.532^{+}$ & 0.295 & 0.071 \\
\hline Sustained supply of fodder (ssf) & $1.033^{* * *}$ & 0.302 & 0.001 \\
\hline Lack of agreement in the community (lagr) & $-2.644^{* * *}$ & 0.524 & 0.000 \\
\hline Ownership of improved cattle breed (imbr) & $0.886^{* *}$ & 0.305 & 0.004 \\
\hline Lack of enforcing community bylaws (laec) & $-0.754 *$ & 0.310 & 0.015 \\
\hline Open cattle grazing (ocgr) & $-0.908 *$ & 0.358 & 0.011 \\
\hline Lack of supervision of development agents (lasda) & -0.495 & 0.302 & 0.102 \\
\hline Low quality of implementation (loqi_1) & -0.317 & 0.292 & 0.277 \\
\hline Low benefits (lobe) & -0.733 * & 0.322 & 0.023 \\
\hline Barrier for farming practices (bafp) & $-0.895^{*}$ & 0.385 & 0.020 \\
\hline Poor participation in planning and decision making (pap) & $-2.331 * * *$ & 0.698 & 0.001 \\
\hline Lack of short term benefits (lasb) & $-1.008 * *$ & 0.336 & 0.003 \\
\hline Constant & $4.759 * * *$ & 0.898 & 0.000 \\
\hline Log likelihood $=-153.4849$ & \multicolumn{2}{|c|}{ Hosmer-Lemeshow test $=0.8432$} & Prob $>\mathrm{chi}^{2}=0.0000$ \\
\hline
\end{tabular}

\section{Discussion}

The findings of this study reveal that a consistent supply of cattle feed from adopted land management methods has a considerable and favorable impact on the long-term viability of land management measures. As cattle fodder is readily available, household heads may easily adopt stall feeding, which decreases open cattle movement and contributes to the long-term sustainability of land management practices. Participants in a focus group discussion noted that access to cattle fodder from adopted land management measures is beneficial in limiting livestock movement, whereas cattle fodder scarcity makes the cutand-carry method difficult and time consuming. The amount of cattle feed available from the adopted land management measures varies across the research area. Some villages with marsh grazing fields have improved cattle fodder access and use stall feeding systems. As livestock movement is restricted in these locations, the adopted land management practices are kept by biological measures on soil bunds and terraces. Other communities, on the other hand, that do not have consistent access to cattle fodder through the cut-and-carry system, practice open grazing on communal grazing grounds and agricultural wastes, resulting in inefficient land management practices. Overall, the focus group discussants agree that if cattle fodder for cut-and-carry systems is available, stall feeding is simple to apply, allowing us to preserve our agricultural plots and land management methods from grazing cattle damage and devastation.

The community's agreement throughout the land management process plays a critical role in the long-term sustainability of the applied land management methods. The importance of community consensus on land management strategies for long-term effects has been highlighted in the empirical literature. One of the reasons for the dis-adoption of the adopted land management strategies, according to Teshome et al. [23], is a lack of interaction with nearby farm owners (low social capital). Table 3 shows that a lack of community agreement during land management activities has a significant and unfavorable impact on the sustainability of the implemented measures. To achieve successful and long-term effects, land management strategies require a collective agreement at the very least at the community level. However, community consensus is difficult to achieve when it comes to land management methods, particularly when it comes to adopting area closures to limit open grazing. Some households require open grazing of cattle, while others want a cut-and-carry grazing technique. Crossland et al. [49] noted two factors that influence the implementation of area closures in northwest Ethiopia: the size of the farmland and the number of cattle owned by a farmer. Farmers with a lot of animals and little or no land rely heavily on communal grazing and are opposed to the implementation of area enclosures. Farmers with enough land and fewer cattle, on the other hand, are 
more inclined to set up area enclosures since they can allocate a portion of the farmland for private grazing. Focus group discussants and key informants also affirm that there is a lack of community consensus on land management practices, particularly when it comes to instituting a cut-and-carry grazing system. Individuals with a big number of cattle are reluctant to employ a cut-and-carry grazing technique because it requires more labor and time to provide fodder grass for that number of animals. In general, a lack of community agreement to establish and maintain land management practices has a major negative impact on its sustainability.

Ownership of improved cattle breeds had a positive impact on the sustainability of the land management measures that had been implemented. Stall feeding is the most common method of raising improved cow breeds for two reasons. The first is that improved cattle breeds are employed for milk production, and the second is that the number of improved cattle breeds is minimal, making fodder easy to get by. In northwestern Ethiopia, farmers with a small herd of animals practice stall feeding [49]. Farmers with better cattle breeds, according to my observations during the transect walk, primarily use stall feeding through the cut-and-carry method, limiting open grazing, which is beneficial to the longterm sustainability of the applied land management methods. Improved cow breeds are cultivated through stall feeding, according to focus group discussants, because they are tiny in size. Such measures reduce cattle movement pressure on farm plots and grazing fields, ensuring the long-term viability of the land management practices in place. Improved cow breeds, according to key informants, contribute more to the sustainability of land management methods by encouraging farmers to employ stall feeding practices. The enhanced breeds are crucial not only for the sustainability of land management practices, but also for the enhancement of rural farmers' incomes, as these breeds are more productive than the indigenous cow breed.

In land management practices, the community establishes several community bylaws to ensure the long-term usage of established land management practices; nevertheless, there are constraints on executing the community bylaws in the study area. The findings of this study show that failing to enforce community rules reduces the long-term viability of land management methods. Obeying community ordinances enacted to preserve land management techniques, notably grazing techniques, as well as to safeguard bush lands and forest remnants from illegal cutting, is a prominent problem. A natural resource conservation committee is formed in each community to monitor and follow up on land management practices. This group is in charge of enforcing the community's bylaws. However, members of natural resource conservation committees do not enforce community regulations, resulting in the unsustainable nature of the established land management practices. Tesfaye et al. [22], in agreement with this finding, addressed how the lack of robust enforcement from watershed committees contributed to the ineffectiveness of watershed management strategies. Participants in the focus group discussion and key informants also revealed that there is a gap in successfully enforcing community regulations because the community is sometimes uncooperative. As a result, the lack of enforcement of community regulations to guarantee the adopted land management methods undermines the sustainability of those measures.

One of the challenges in land management strategies is open cattle grazing. As shown in Table 3, open grazing of cattle impairs the sustainability of the implemented land management practices in the research area. In northeastern Ethiopia, a study by Zeweld et al. [50] found that farmers prefer unrestricted grazing of cattle on communal grazing areas and farm plots after harvest rather than using controlled grazing systems. Open grazing of cattle has become a serious barrier to the sustainability of the established land management practices, according to the focus group discussants and key informants. According to the focus group discussants, the reasons for open grazing are: (i) the number of cattle is vast, making it difficult to provide fodder through the cut-and-carry system; and (ii) grass is limited, making collecting it through a cut-and-carry method time consuming and tedious. After crop harvest, free cattle grazing in communal grazing areas and on farm 
plots destroys the built-in land management structures and grazes biological measures such as grass and plant species. Cattle graze freely on shrubs and grasses planted for sustaining land management structures in Wereillu Woreda after grain harvest [51], and as a result, new soil and water conservation methods are introduced at the same farm plot year after year. Farmers recognize the importance of biological conservation measures such as grass strips and hedgerow barriers in conserving soil and water, increasing crop diversity, and maintaining agro-ecological balance [52], but free grazing in the Koga catchment makes these land management practices unsustainable. Open grazing systems significantly reduce the sustainability of implemented soil and water conservation structures $[53,54]$. Cut-andcarry grazing systems must be stressed in order to achieve effective land management methods. According to Hishe et al. [55] and Etsay et al. [56], implementing a zero grazing system makes land management methods more successful and allows for the predicted benefits to be realized.

The advantages achieved from the implemented land management practices have a significant impact in the likelihood of the established land management practices' sustainability. If a farmer receives the expected advantages from the implemented land management methods, he or she is more likely to continue using them; on the other hand, if the benefits are minimal, the likelihood of continuing to use the methods decreases. As shown in Table 3, the low benefits of the established land management activities reduce the sustainability of the implemented land management practices significantly. Teshome et al. [23] and Adimassu et al. [57] reinforce this fact, stating that the profitability or increased benefits of the applied land management measures motivate farmers to utilize them constantly through maintenance, and the opposite is also true. The profitability of the established land management strategies has a crucial impact on its sustainability [58]. In general, the focus group discussants concluded that the benefits of the existing land management methods are less than we anticipated which discourages us from implementing new ones or maintaining those that have already been implemented.

The findings of this study show that implemented land management structures that act as a barrier to farming practices have a considerable detrimental impact on their longterm viability. Due to the difficulty of turning oxen in between the established structures during the plowing season, farmers dismantle the existing land management methods. According to Assefa and Hans-Rudolf [59], one of the reasons for the abandonment of previously applied land management measures in the Gamo highlands is the difficulty of plowing between structures, as oxen plows require more space. Teshome et al. [23] discovered that problems for oxen plowing in northwestern Ethiopia were one of the causes behind the dis-adoption of land management practices. The focus group discussants also agree that because the implemented land management structures are built close together, it is difficult to plow between them, especially when turning oxen. As a result, the only choice is to remove the land management structures that have been put in place during the main farming season and then undertake maintenance after sowing our farm plots.

Farmers (household heads) must be included in the planning and decision-making processes of land management practices in order to develop a consensus on the entire process of sustainable land management practices. According to Abi et al. [60], an integrated and participatory strategy is required to instill responsibility in household heads and to ensure that land management methods have a long-term impact. Poor participation of household heads in planning and decision-making processes, on the other hand, impedes the efficacy of land management methods that have been established. As the regression result shows, low participation of household heads in planning and decision-making processes has a major impact on the sustainability of the land management methods that have been implemented. Participants in the focus group discussion also confirmed that the mass household head's participation in planning and decision-making processes is limited, and that only a few selected representatives discuss the issue with development agents and Woreda natural resource experts before the public is called to implement land management practices. Though the practice varies, Jemberu et al. [52] and the Food and 
Agriculture Organization (FAO) [61] both strongly advocate for the full engagement of all stakeholders in the planning and decision-making of land management methods. In northwest Ethiopia, inefficient soil and water conservation efforts were caused by farmers' lack of engagement in decision-making and planning of land management methods [62]. Similarly, Mekuriaw et al. [54] and Alemu et al. [63] addressed how a lack of community participation in planning and decision-making processes is one of the main reasons for poor land management practice implementation. Due to a lack of engagement in defining problems such as for what purpose is a practice implemented and how is it utilized, including who is the owner of the protected area, land management practices, particularly enforcing area closures, are ineffective. Farmers believe that by instituting a cut-and-carry grazing system through area closures, this protected area will be acquired by the government or offered to investors. They believe that prohibiting cattle movement in certain regions is the government's first step in seizing land for its own purposes, and that agreeing to practice area closures is tantamount to authorizing the government to seize land for its own purposes. These issues develop as a result of the household heads' lack of participation in gaining a comprehensive grasp of the area closures that are practiced in their area.

As a farmer prefers to generate farm goods by removing the existing land management techniques due to the lack of short-term benefits, the sustainability of the established land management measures is decreased. Table 3 confirms this by demonstrating that the lack of short-term benefits from the implemented land management techniques reduces the sustainability of the implemented land management practices greatly. Farmers who saw sustainable land management practices as unprofitable and lacking in short-term benefits did not like to employ them [58]. Furthermore, Mekuriaw et al. [54] noted that, while farmers require immediate advantages from land management measures that have been implemented, realistic short-term gains are limited. While households acknowledge the importance of adopting sustainable land management, Yimer [64] discovered that the longer time horizon required to see benefits has become a problem. Farmers prefer to remove the implemented land management measures for producing crops since the benefits of land management practices take a long time to reap and they require instant benefits to maintain their livelihoods, according to key informants and focus group discussants.

\section{Conclusions}

This study looked at the factors that influence the long-term sustainability of land management practices. Several factors influence the sustainability of land management practices that have been implemented. Sustained supply (availability) of cattle fodder from established land management methods, as well as improved cow breeds, have been demonstrated to be extremely beneficial to the long-term viability of established land management methods. The lack of agreement (consensus) among household heads, especially when it comes to implementing area closure (protected grazing), undermines the sustainability of the land management methods that have been established. On both farm plots and communal grazing fields, a lack of experience with stall feeding and open (free) grazing reduces the effectiveness of the established land management methods. The problem stems from two factors: a huge number of cattle that are difficult to manage through stall feeding, and a paucity of cattle fodder for the cut-and-carry technique. The poor short-term advantages of land management methods deter family heads from maintaining the measures that have already been implemented. Household heads were also apathetic to the implemented land management practices due to their lack of engagement in planning and decision-making procedures. Introducing fast growing grass species for a cut-and-carry system of grazing (stall feeding practice) and raising public awareness about the productivity of a small number of cattle through the introduction of improved breeds should be prioritized for the long-term sustainability of land management practices and the improvement of farmers livelihoods. Another point worth mentioning is permitting full participation of household heads in land management practice planning and decision-making processes, as well as incorporating short-term benefits in land management methods, in order to make land 
management practices sustainable in the study region. Finally, more research is needed to determine the long-term sustainability of land management strategies depending on criteria such as landholding size, age, and educational status of household heads.

Author Contributions: This research was conducted under the supervision of D.T. and A.B.; conceptualization and methodology, H.N., D.T. and A.B. The draft was prepared by H.N. and reviewed and edited by D.T. and A.B. All authors have read and agreed to the published version of the manuscript.

Funding: This research received no external funding.

Institutional Review Board Statement: Not applicable.

Informed Consent Statement: Not applicable.

Data Availability Statement: The data presented in this study are available on request from the corresponding author.

Acknowledgments: We would like to thank College of Development Studies, Addis Ababa University and the household heads of the study area.

Conflicts of Interest: The authors declare no conflict of interest.

\section{References}

1. Agricultural Transformation Agency (ATA). Transforming Agriculture in Ethiopia; ATA: Addis Ababa, Ethiopia, 2014.

2. Gessesse, B.; Bewket, W.; Bräuning, A. Determinants of farmers' tree-planting investment decisions as a degraded landscape management strategy in the central highlands of Ethiopia. Solid Earth 2016, 7, 639-650. [CrossRef]

3. Kassie, M.; Jaleta, M.; Shiferaw, B.; Mmbando, F.; Mekuria, M. Adoption of interrelated sustainable agricultural practices in smallholder systems: Evidence from rural Tanzania. Technol. Forecast. Soc. Chang. 2013, 80, 525-540. [CrossRef]

4. Amede, T.; Kassa, H.; Zeleke, G.; Shiferaw, A.; Kismu, S.; Teshome, M. Working with communities and building local institutions for sustainable land management in the Ethiopian Highlands. Mt. Res. Dev. 2007, 27, 15-19. [CrossRef]

5. Kassie, M.; Zikhali, P.; Pender, J.; Köhlin, G. The economics of sustainable land management practices in the Ethiopian Highlands. J. Agric. Econ. 2010, 61, 605-627. [CrossRef]

6. Gashaw, T.; Bantider, A.; Gebresilassie, H. Land degradation in Ethiopia: Causes, impacts and rehabilitation techniques. J. Environ. Earth Sci. 2014, 4, 98-105.

7. Birhanu, A. Environmental degradation and management in Ethiopian Highlands: Review of lessons learned. Int. J. Environ. Prot. Policy 2014, 2, 24. [CrossRef]

8. Wolancho, K.W. Evaluating watershed management activities of campaign work in Southern nations, nationalities and peoples' regional state of Ethiopia. Environ. Syst. Res. 2015, 4, 6. [CrossRef]

9. Deichert, G.; Krämer, F.; Schöning, A. Turning degraded land into productive landscapes, Ethiopian Highlands. ETFRN NEWS 2014, 56, 82-87.

10. Demissie, S. Perception of farmers toward physical soil and water conservation structures in Wyebla Watershed, Northwest Ethiopia. Acad. J. Plant Sci. 2015, 7, 34-40. [CrossRef]

11. Gabathuler, E.; Liniger, H.; Hauert, C.; Giger, M. Benefits of Sustainable Land Management; WOCAT: Bern, Switzerland, 2009; pp. 1-16. [CrossRef]

12. Cordingley, J.; Snyder, K.; Rosendahl, J.; Kizito, F.; Bossio, D. Thinking outside the plot: Addressing low adoption of sustainable land management in sub-Saharan Africa. Curr. Opin. Environ. Sustain. 2015, 15, 35-40. [CrossRef]

13. Woodfine, A.C.; Vallee, D.; Bunning, S.; Sinnassamy, J.M. Informing Future Investment for Scaling Up Sustainable Land Management in Sub-Saharan Africa: Lessons from the Strategic Investment Programme (SIP); TerrAfrica: Midrand, South Africa, 2016.

14. Motavalli, P.P.; Nelson, K.; Udawatta, R.P.; Jose, S.; Bardhan, S. Global achievements in sustainable land management. Int. Soil Water Conserv. Res. 2013, 1, 1-10. [CrossRef]

15. Marques, M.J.; Schwilch, G.; Lauterburg, N.; Crittenden, S.; Tesfai, M.; Stolte, J.; Zdruli, P.; Zucca, C.; Petursdottir, T.; Evelpidou, N.; et al. Multifaceted impacts of sustainable land management in drylands: A review. Sustainability 2016, 8, 177. [CrossRef]

16. Global Environment Facility. Sustainable Land Management and Its Relationship to Global Environmental Benefits and Food Security-A Synthesis Report for the GEF; Global Environment Facility: Washington, DC, USA, 2016; pp. 1-9.

17. Henry, B.; Murphy, B.; Cowie, A. Sustainable Land Management for Environmental Benefits and Food Security-A Synthesis report for the GEF; Global Environment Facility: Washington, DC, USA, 2018; p. 127.

18. Haregeweyn, N.; Tsunekawa, A.; Nyssen, J.; Poesen, J.; Tsubo, M.; Meshesha, D.T.; Schütt, B.; Adgo, E.; Tegegne, F. Soil erosion and conservation in Ethiopia: A review. Prog. Phys. Geogr. Earth Environ. 2015, 39, 750-774. [CrossRef]

19. Gebremedhin, B.; Woldewahid, G.; Dessalegn, Y.; Gebey, T.; Teka, W. Sustainable land management through market oriented commodity development: Case studies from Ethiopia. IPMS Work. Pap. 2010, 21, 42.

20. Amsalu, A.; De Graaff, J. Determinants of adoption and continued use of stone terraces for soil and water conservation in an Ethiopian highland watershed. Ecol. Econ. 2007, 61, 294-302. [CrossRef] 
21. Sileshi, M.; Kadigi, R.; Mutabazi, K.; Sieber, S. Determinants for adoption of physical soil and water conservation measures by smallholder farmers in Ethiopia. Int. Soil Water Conserv. Res. 2019, 7, 354-361. [CrossRef]

22. Tesfaye, G.; Alamirew, T.; Kebede, A.; Zeleke, G. Institutional Functionality in participatory integrated watershed development of Tana Sub-Basin, Ethiopia. Land 2018, 7, 130. [CrossRef]

23. Teshome, A.; De Graaff, J.; Kessler, A. Investments in land management in the north-western highlands of Ethiopia: The role of social capital. Land Use Policy 2016, 57, 215-228. [CrossRef]

24. Kassie, M.; Yesuf, M.; Köhlin, G. The role of production risk in sustainable land-management technology adoption in the Ethiopian Highlands. EfD Discuss. Pap. 2008, 8, 29.

25. Zeleke, G.; Kassie, M.; Pender, J.; Yesuf, M. Stakeholder Analysis for Sustainable Land Management (SLM) in Ethiopia: Assessment of Opportunities, Strategic Constraints, Information Needs, and Knowledge Gaps; Environmental Economics Policy Forum for Ethiopia: Addis Ababa, Ethiopia, 2006; p. 96.

26. Adimassu, Z.; Langan, S.; Johnston, R. Understanding determinants of farmers' investments in sustainable land management practices in Ethiopia: Review and synthesis. Environ. Dev. Sustain. 2016, 18, 1005-1023. [CrossRef]

27. Bewket, W. Soil and water conservation intervention with conventional technologies in northwestern highlands of Ethiopia: Acceptance and adoption by farmers. Land Use Policy 2007, 24, 404-416. [CrossRef]

28. Dejene, A. Integrated natural resources management to enhance food security-The case for community-based approaches in Ethiopia. Environ. Nat. Resour. Work. Pap. 2003, 16, 58.

29. Tefera, B.; Sterk, G. Land management, erosion problems and soil and water conservation in Fincha'a watershed, western Ethiopia. Land Use Policy 2010, 27, 1027-1037. [CrossRef]

30. Tesfaye, A.; Negatu, W.; Brouwer, R.; Van Der Zaag, P. Understanding soil conservation decision of farmers in the Gedeb Watershed, Ethiopia. Land Degrad. Dev. 2013, 25, 71-79. [CrossRef]

31. Teshome, A.; De Graaff, J.; Ritsema, C.; Kassie, M. Farmers' perceptions about the influence of land quality, land fragmentation and tenure systems on sustainable land management in the North Western Ethiopian Highlands. Land Degrad. Develop. 2014, 27, 884-898. [CrossRef]

32. Abebe, Z.D.; Sewnet, M.A. Adoption of soil conservation practices in North Achefer District, Northwest Ethiopia. Chin. J. Popul. Resour. Environ. 2014, 12, 261-268. [CrossRef]

33. Fentie, D.; Fufa, B.; Bekele, W. Determinants of the use of soil conservation technologies by smallholder farmers: The case of Hulet Eju Enesie District, East Gojjam Zone, Ethiopia. Asian J. Agric. Food Sci. 2013, 1, 119-138.

34. Teklewold, H.; Kassie, M.; Shiferaw, B. Adoption of multiple sustainable agricultural practices in rural Ethiopia. J. Agric. Econ. 2013, 64, 597-623. [CrossRef]

35. Adimassu, Z.; Kessler, A. Farmers' investments in land management practices in the CRV of Ethiopia. In Proceedings of the 8th International Symposium Agro. Environ, Wageningen, The Netherlands, 1-4 May 2012.

36. Shiferaw, B.A.; Okello, J.; Reddy, R.V. Adoption and adaptation of natural resource management innovations in smallholder agriculture: Reflections on key lessons and best practices. Environ. Dev. Sustain. 2007, 11, 601-619. [CrossRef]

37. Pender, J.; Gebremedhin, B. Determinants of Agricultural and land management practices and impacts on crop production and household income in the highlands of Tigray, Ethiopia. J. Afr. Econ. 2007, 17, 395-450. [CrossRef]

38. Wossen, T.; Berger, T.; Di Falco, S. Social capital, risk preference and adoption of improved farm land management practices in Ethiopia. Agric. Econ. 2015, 46, 81-97. [CrossRef]

39. Wossen, T.; Berger, T.; Mequaninte, T.; Alamirew, B. Social network effects on the adoption of sustainable natural resource management practices in Ethiopia. Int. J. Sustain. Dev. World Ecol. 2013, 20, 477-483. [CrossRef]

40. Belay, M.; Bewket, W. Farmers' livelihood assets and adoption of sustainable land management practices in north-western highlands of Ethiopia. Int. J. Environ. Stud. 2013, 70, 284-301. [CrossRef]

41. Molla, T.; Hassen, A.; Kassa, B.; Berihun, B.; Tolla, M.; Denekew, Y.; Gebresellassie, Y.; Tegegne, F. Participatory Rural Appraisal Report: Mecha Woreda, Amhara Region; CASCAPE: Bahir Dar, Ethiopia, 2014.

42. Getahun, M. Characterisation of Agricultural Soils in Cascape Intervention Woredas of Amhara Region; CASCAPE: Bahir Dar, Ethiopia, 2015.

43. Tasew, A.; Eyassu, S. Small holder dairy production system and emergence of dairy cooperatives in Bahir Dar Zuria and Mecha Districts, Northwestern Ethiopia. World J. Dairy Food Sci. 2009, 4, 185-192.

44. Creswell, J.W. Educational Research: Planning, Conducting and Evaluating Quantitative and Qualitative Research, 4th ed.; Pearson Education: London, UK, 2012.

45. Israel, G.D. Determining Sample Size; University of Florida: Gainesville, FL, USA, 1992; pp. 1-5.

46. World Bank. Sustainable Land Management: Challenges, Opportunities, and Trade-offs; World Bank: Washington, DC, USA, 2006.

47. Hurni, H. Precious Earth: From Soil and Water Conservation to Sustainable Land Management; ISCO: Bern, Switzerland, 1996. [CrossRef]

48. Liniger, H.; Mekdaschi, R.; Hauert, C.; Gurtner, M. Sustainable Land Management in Practice-Guidelines and Best Practices for Sub-Saharan Africa; FAO: Rome, Italy, 2011.

49. Crossland, M.; Winowiecki, L.A.; Pagella, T.; Hadgu, K.; Sinclair, F. Implications of variation in local perception of degradation and restoration processes for implementing land degradation neutrality. Environ. Dev. 2018, 28, 42-54. [CrossRef] 
50. Zeweld, W.; Van Huylenbroeck, G.; Tesfay, G.; Azadi, H.; Speelman, S. Impacts of Socio-psychological factors on actual adoption of sustainable land management practices in dryland and water stressed areas. Sustainability 2018, 10, 2963. [CrossRef]

51. Asfaw, D.; Neka, M. Factors affecting adoption of soil and water conservation practices: The case of Wereillu Woreda (District), South Wollo Zone, Amhara Region, Ethiopia. Int. Soil Water Conserv. Res. 2017, 5, 273-279. [CrossRef]

52. Jemberu, W.; Baartman, J.E.; Fleskens, L.; Ritsema, C.J. Participatory assessment of soil erosion severity and performance of mitigation measures using stakeholder workshops in Koga catchment, Ethiopia. J. Environ. Manag. 2018, 207, 230-242. [CrossRef] [PubMed]

53. Nigussie, Z.; Tsunekawa, A.; Haregeweyn, N.; Adgo, E.; Nohmi, M.; Tsubo, M.; Aklog, D.; Meshesha, D.T.; Abele, S. Farmers' perception about soil erosion in Ethiopia. Land Degrad. Dev. 2017, 28, 401-411. [CrossRef]

54. Mekuriaw, A.; Heinimann, A.; Zeleke, G.; Hurni, H. Factors influencing the adoption of physical soil and water conservation practices in the Ethiopian highlands. Int. Soil Water Conserv. Res. 2018, 6, 23-30. [CrossRef]

55. Hishe, S.; Lyimo, J.; Bewket, W. Soil and water conservation effects on soil properties in the Middle Silluh Valley, northern Ethiopia. Int. Soil Water Conserv. Res. 2017, 5, 231-240. [CrossRef]

56. Etsay, H.; Negash, T.; Aregay, M. Factors that influence the implementation of sustainable land management practices by rural households in Tigrai region, Ethiopia. Ecol. Process. 2019, 8, 14. [CrossRef]

57. Adimassu, Z.; Langan, S.; Johnston, R.; Mekuria, W.; Amede, T. Impacts of soil and water conservation practices on crop yield, run-off, soil loss and nutrient loss in Ethiopia: Review and synthesis. Environ. Manag. 2017, 59, 87-101. [CrossRef]

58. Nigussie, Z.; Tsunekawa, A.; Haregeweyn, N.; Adgo, E.; Nohmi, M.; Tsubo, M.; Aklog, D.; Meshesha, D.T.; Abele, S. Factors influencing small-scale farmers' adoption of sustainable land management technologies in north-western Ethiopia. Land Use Policy 2017, 67, 57-64. [CrossRef]

59. Assefa, E.; Hans-Rudolf, B. Indigenous resource management practices in the Gamo Highland of Ethiopia: Challenges and prospects for sustainable resource management. Sustain. Sci. 2017, 12, 695-709. [CrossRef]

60. Abi, M.; Kessler, A.; Oosterveer, P.; Tolossa, D. Adapting the current mass mobilization approach in Ethiopia to enhance its impact on sustainable land management: Lessons from the Sago-kara watershed. J. Environ. Manag. 2019, 248, 109336. [CrossRef]

61. Food and Agriculture Organization (FAO). Sustainable Land Management (SLM) in Practice in the Kagera Basin. Lessons Learned for Scaling Up at Landscape Level: Results of the Kagera Transboundary Agro-Ecosystem Management Project (Kagera TAMP); Food and Agriculture Organization of the United Nations: Rome, Italy, 2017; p. 440.

62. Moges, D.M.; Taye, A.A. Determinants of farmers' perception to invest in soil and water conservation technologies in the North-Western Highlands of Ethiopia. Int. Soil Water Conserv. Res. 2017, 5, 56-61. [CrossRef]

63. Alemu, G.T.; Tsunekawa, A.; Haregeweyn, N.; Nigussie, Z.; Tsubo, M.; Elias, A.; Ayalew, Z.; Berihun, D.; Adgo, E.; Tsegaye, D.; et al. Smallholder farmers' willingness to pay for sustainable land management practices in the Upper Blue Nile basin, Ethiopia. Environ. Dev. Sustain. 2020, 23, 5640-5665. [CrossRef]

64. Yimer, M. The effect of sustainable land management (SLM) to ensure food security; local evidences from Tehuledere Woreda, ANRS, Northern Ethiopia. Sci. J. Crop Sci. 2015, 4, 1-27. 